\title{
Rangelands of Band-e-Amir National Park and Ajar Provisional Wildlife Reserve, Afghanistan
}

\section{By Donald J. Bedunah, Christopher C. Shank, and Muhammad Ayub Alavi}

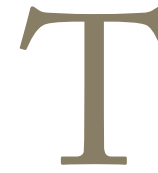

he Islamic Republic of Afghanistan (Afghanistan) is a country dominated by rangeland ecosystems. These rangelands are critically important to Afghanistan for their role in supplying forage for livestock, wildlife habitat, watersheds, and open space, as well as other values. The many years of war and conflict in Afghanistan have had many devastating impacts, including significant loss of life, increased illiteracy and poverty, reduced health care, and other problems that continue to threaten the security of Afghanistan. In some ways the concern for natural resource conservation might seem of low importance compared with other problems in Afghanistan, but the management of natural resources is critical to livelihoods and poverty reduction and directly related to security issues of land use. Since 2006, the Wildlife Conservation Society (WCS), with funding from the U.S. Agency for International Development, has worked with the Afghan government and other nongovernment organizations to help Afghans provide better natural resource management. During 2007-2008 we worked with WCS in two areas in central Afghanistan with a history of conservation and protection of resources (Fig. 1) to determine conservation issues and to provide recommendations for improved management. One area, Band-e-Amir National Park, was established as Afghanistan's first national park in 2009. The second area, the former Ajar Wildlife Refuge, is not currently legally recognized. Neither area has effective conservation. As rangelands are the dominant land type in these areas, we initiated a rapid rangeland reconnaissance in 2007-2008 and interviewed local people to determine concerns regarding rangeland issues. In this article, we describe the rangelands and people who use Band-e-Amir National Park (Band-e-Amir NP) and Ajar provisional wildlife reserve (Ajar PWR) and discuss major natural resource problems. We begin with a brief history centering on Bamyan Province and the main ethnic group, the Hazara. The changing historic use will not be stressed, but certainly past conflicts continue to result in insecurity of land rights and thus problems in natural resource management.

\section{The Region: Its History and People}

Humans have exerted a significant influence on the central highlands of Afghanistan for many centuries, if not for thousands of years. A major segment of the silk route passed through Bamyan, and it is known that Bamyan town was settled more than 2,000 years ago. Bamyan Province (sometimes spelled Bamiyan or Bamian) is one of 34 provinces of Afghanistan and is located in the west-central Hindu Kush Mountains. The dominant ethnic group in Bamyan is the Hazara. They are Shia Muslims, unlike most other Afghans, who are Sunni Muslims. As the Hazaras practice a different form of Islam and look different from other ethnic groups in the region, there is significant discrimination and repression of Hazara people. ${ }^{1}$ Both Hazaras and Tajiks use the Ajar PWR. But the majority of users are Hazara, and all villages in Band-e-Amir are Hazara. The Hazaras are often considered descendents of Ghengis Khan's great army that conquered Afghanistan in the 13th century, but certainly people have occupied Bamyan and the surrounding areas for much longer. The Buddha statues of Bamyan (destroyed by the Taliban in 2001) are believed to have been constructed in the sixth century $\mathrm{AD}$. Alexander the Great was in Afghanistan 2,300 years ago, and there is no reason to believe that nomads have not used the central highlands of Afghanistan for thousands of years. They have relied on vertical migrations to take advantage of changes in the grazing resources with changing altitudes. 




Figure 1. Study area overview.

Until the 1880s, the Hazaras were autonomous and in control of all areas in Hazarajat (the region dominated by Hazaras or their heartland). ${ }^{2}$ Livestock were a mainstay of the Hazara economy with reports of one feudal chief possessing more than 69,000 horses in his cavalry during the 19th century (Ferrier 1857 from Mousavi). ${ }^{2}$ The loss of control of Hazara pastures occurred in the 1890s. During this time the leader of Afghanistan, Abdur Rahman, "the Iron Amir," invaded and conquered the Hazarajat with Ghilzai tribal (Pashtun) support, reduced thousands of the former inhabitants to slavery, and settled the Ghilzai on much of the land. ${ }^{1}$ Abdur Rahman forced migration of several tribes in order to weaken these groups and dilute tribal structures in the areas in which they were moved. The result was a loss of control of many Hazara pasturelands to nomadic Pashtu, called kuchi, who migrated into the highlands from their winter and spring pastures. Over a century ago, most kuchi used Pakistan as a major grazing zone and did not venture into this area. ${ }^{3}$

In more recent times the Hazaras, Tajiks, and Uzbeks were the main ethnic groups of the Northern Alliance that battled the Taliban in the early and mid-1990s. In September 1998, the Taliban occupied Bamyan town, and the Hazaras were persecuted by the Taliban. Taliban forces not only destroyed the fifth-century Buddhas, but also burned down more than 4,000 homes, shops, and public buildings and destroyed entire towns in western Bamyan Province. ${ }^{4}$ The Band-e-Amir area was a front line in fighting between the Taliban and the Northern Alliance in 2001 and was heavily mined. Most of the local population fled the area, with many migrating to Iran, but since have returned. De-mining teams have now made the area safe. The consequences of these conflicts is continued mistrust between ethnic groups, continued violence, and continued disputes regarding pasture use in many areas between Hazaras and kuchi. Kuchi continue to claim pasture rights from decrees during Abdur Rahman's reign in much of the central highlands of Afghanistan. Land security continues to be a difficult issue facing the Afghan government, 3,5 with conflicts over pasture use remaining a significant problem. In Band-e-Amir NP and Ajar PWR it is unknown if conflicts between kuchi and local Hazara have occurred in the last few years, but there 


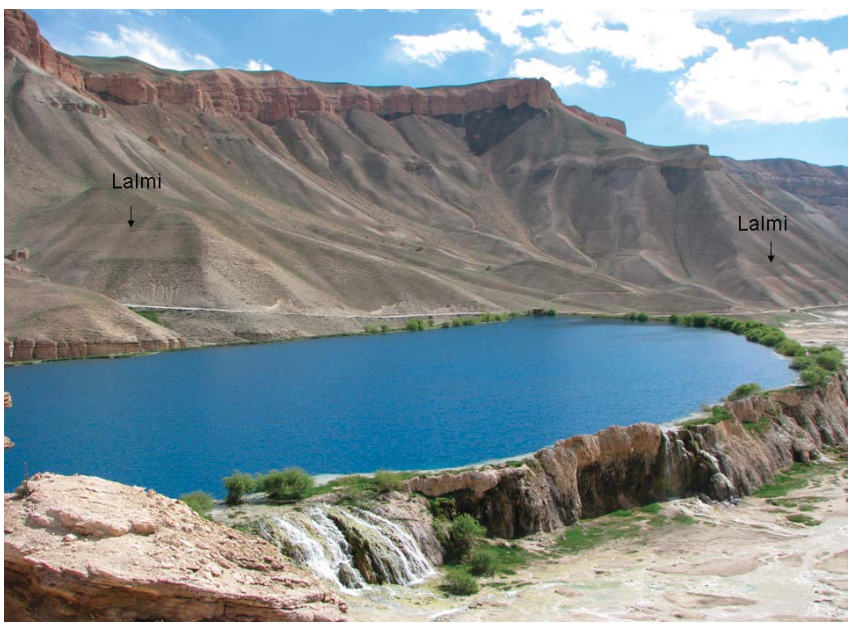

Figure 2. Photo of one of the Band-e-Amir lakes illustrating travertine dam and red cliffs that surround the lakes. Note plowed areas (la/mi) on steep hillsides.

is little doubt that local people are concerned about land use rights.

\section{Overview of Band-e-Amir NP and Ajar PWR}

Band-e-Amir NP is an area of dramatic landscapes encompassing 59,648 ha and established to protect six major lakes (Fig. 2). A band is a Dari term referring to either a dam or the water behind the dam. Band-e-Amir NP is a BirdLife International Important Bird Area of global significance with 174 species recorded in the WorldBirds Database. Native ungulates such as urial (Ovis orientalis) are rare because of past hunting and degradation of habitat. Wolf (Canis lupus), fox (Vulpes vulpes), pikas (Ochotona rufescens), and a variety of other small mammals persist. Four species of plants are known to be endemic to Band-e-Amir NP. ${ }^{6}$ Band-e-Amir received a significant number of foreign tourists in the 1950s to 1970s, but very few have visited since the beginning of the war, although domestic tourism is currently thriving.

Ajar PWR is an area of rugged rangelands dissected by numerous canyons providing critical wildlife habitat. The boundaries have not been precisely delineated, but current discussions have established a proposed boundary containing 29,601 ha. The main canyon is the Jawzari Canyon (Dara-i-Jawzari) formed as the Ajar River eroded its way through limestone to form the narrow canyon. In the recent geological past, the river became subterranean, leaving Dara-i-Jawzari dry. The Ajar River now flows directly out of the rock wall into the canyon at the spring of Chiltan, which has religious and cultural significance to local people. The rulers of Afghanistan began using the area as a royal hunting area in early 20th century, and in 1950 restrictions

i http://www.worldbirds.org/mapportal/worldmap.php. Accessed 15 November 2009.

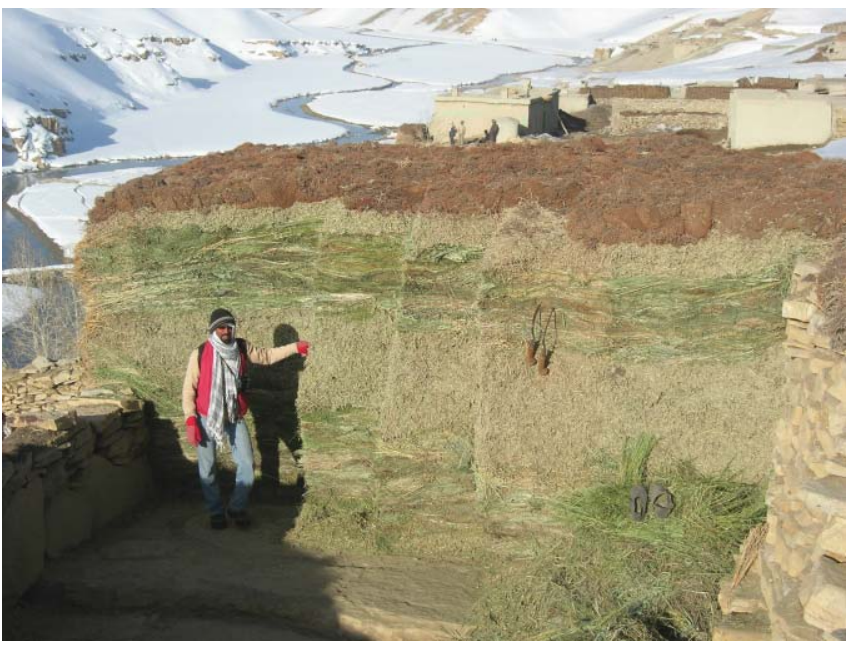

Figure 3. Photo of a die, which is the stored feed for winter feeding of animals.

were established that significantly restricted livestock grazing and other land uses. At this time the Ajar rangelands were in the best condition of any rangelands in the central highlands and possibly all of Afghanistan. ${ }^{7}$ With the overthrow of the monarchy in 1973, the area became a government-controlled wildlife sanctuary. ${ }^{8}$ During the mid-1970s the ibex (Capra ibex) population was more than 2,500 with estimates of $5,000 .{ }^{8}$ Other species of note occupying the Ajar Valley were urial and introduced Bactrian deer (Cervus elaphus bactrianus), common leopard (Panthera pardus), lynx (Lynx lynx), wolf, fox, river otter (Lutra lutra), and marten (Martes foina). Following the collapse of a functioning Afghan government in about 1980 and subsequent years of conflict, protection of natural resources ceased to exist.

The local people using Band-e-Amir NP and Ajar PWR are agro-pastoralists. Some graze flocks from summer encampments (ailogs) while some remain near villages to farm. There are traditional summer and winter ranges. During winter livestock are grazed near villages and during heavy snow are fed wheat straw, reeds, and various harvested forbs and shrubs called a die or special "pile" of animal fodder (Fig. 3). The main crops are wheat and barley, although fruits and vegetables are grown in some areas near Ajar PWR. There are 15 villages in Band-e-Amir NP with a total population of about 4,775 people. ${ }^{9}$ The major areas of cultivation are in stream valleys, but grain is also grown on uplands, where dryland farming called lalmi is widely distributed throughout Band-e-Amir NP. In Ajar PWR there are no villages, although several are located in proximity. Local people from these villages use Ajar PWR for livestock grazing and for collecting shrubs and other plants for household uses and for sale in local markets. Only small areas of Ajar PWR have been used for farming, probably because most of the area is too dry, rocky, or steep. Both areas receive significant livestock grazing by sheep, goats, donkeys, horses, and cattle. Horses are used for transport 

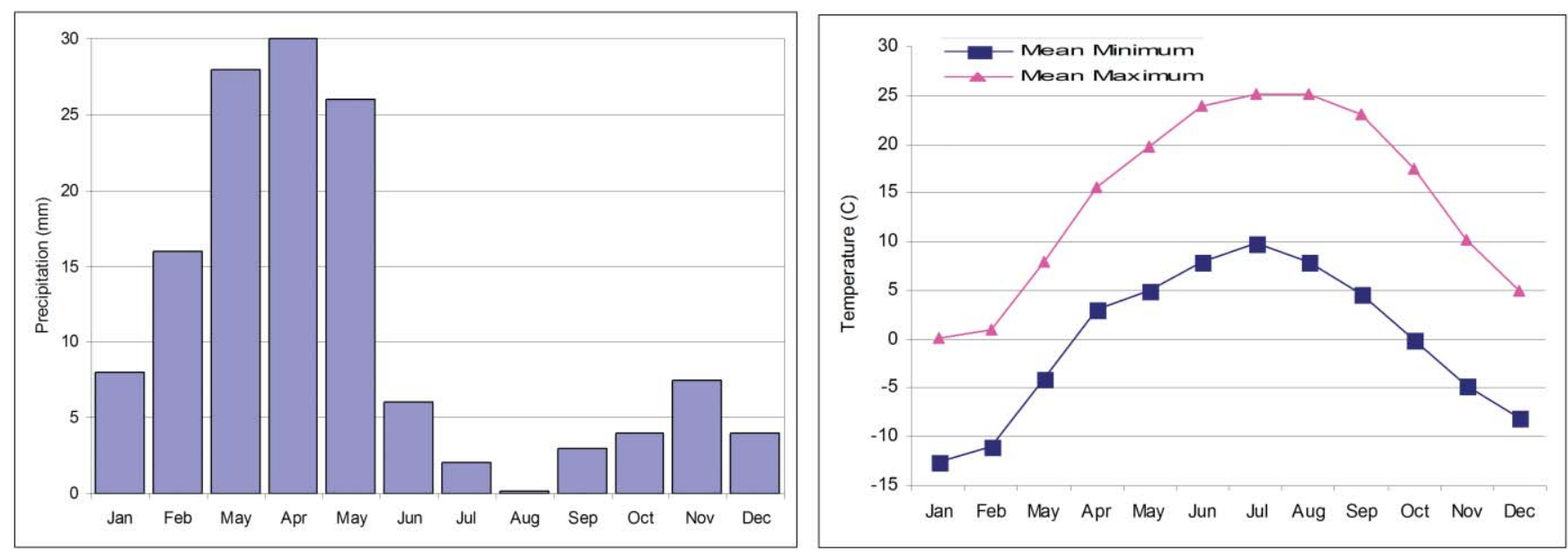

Figure 4. Mean monthly precipitation at Bamyan town (www.allmetsat.com; accessed 10 March 2010).

and sport (including the Afghan national game of buzkashi). Donkeys are used to transport loads, especially shrubs used for fuels. The sheep are a fat-tailed sheep that supply meat, milk, and fiber to local people. The wool and hair from sheep and goats are used to make clothes, carpets, blankets, and felt. Cattle are important for meat, draft, and dairy products.

\section{Rangeland Overview}

The rangelands of Band-e-Amir NP and Ajar PWR vary from semidesert shrublands to wetlands, but shrub steppe dominates both areas. The latitude is about 35 degrees north and thus similar to Albuquerque, New Mexico. Elevation ranges from 1,924 $\mathrm{m}$ to $4,035 \mathrm{~m}(6,253-13,114$ feet) in Ajar PWR and 2,742 $\mathrm{m}$ to $3,902 \mathrm{~m}(8,912-12,682$ feet $)$ in Bande-Amir NP. Site classification systems such as ecological sites or habitat types do not exist in Afghanistan, so our description of rangelands is based on general aspects related to dominant present cover. No known climate site data are available, but the regional climate is continental with significant climate differences associated with elevation differences. The closest weather station is in Bamyan City, located about $70 \mathrm{~km}$ southeast of Ajar Valley and $55 \mathrm{~km}$ (34 miles) east of Band-e-Amir NP. This station, at an elevation of 2,550 m, reports an annual average of $130 \mathrm{~mm}$ (5.1 inches) of precipitation (Fig. 4). Annual precipitation was estimated to vary from about $160 \mathrm{~mm}$ (6.3 inches) in the valley bottoms to over $400 \mathrm{~mm}$ ( 15.7 inches) in the upper mountainous sections of the Ajar area. Band-e-Amir $\mathrm{NP}$, lying mostly above $3,000 \mathrm{~m}$, is colder and wetter than Bamyan City. ${ }^{7}$ Band-e-Amir NP may receive as much as $400 \mathrm{~mm}$ (16 inches) of precipitation annually. ${ }^{10}$ Snow becomes an important factor in plant community formation, especially at higher elevations.

As climate site data were limited, we obtained annual net primary production (ANPP) estimates from 2000-2006 and six years of 16-day normalized difference vegetation index (NDVI) composites using 250-m resolution Moderate Resolution Imaging Spectroradiometer (MODIS) data, as additional means of examining climate variability. ANPP was obtained by subsetting $1 \mathrm{~km}$ global data. ${ }^{11}$ ANPP averaged 119 and $108 \mathrm{~g}$ of carbon (C) per square meter for Ajar PWR and Band-e-Amir NP, respectively, for the years 2000 and 2006 (Fig. 5). The ANPP is similar to drygrassland types with a significant desert shrub component found in North America. ${ }^{12}$ Yearly maximum and minimum NPP were $113 \mathrm{~g} \mathrm{C} / \mathrm{m}^{2}$ and $126 \mathrm{~g} \mathrm{C} / \mathrm{m}^{2}$ for Ajar PWR and 99-117 $\mathrm{g} \mathrm{C} / \mathrm{m}^{2}$ for Band-e-Amir NP Valley, which over the seven-year period showed relatively low annual variability in ANPP. The NDVIs did show significant variability, both spatial and temporal, of snow cover, "green-up" of vegetation, and maximum green vegetation during a six-year period. Maximum green vegetation was recorded on Julian day 161 (15 June) and 177 (26 June) for Ajar PWR and Band-e-Amir NP, respectively (Fig. 6), but varied by a month depending on the year. By 1 November (Julian Day 305) snow cover is common at higher elevations, and from Julian Day 321 to 65 (17 November to 6 March) snow covers most of Band-e-Amir NP (Ajar PWR has approximately two to four weeks less average snow cover). Likewise, the timing of vegetation "green-up" on years examined averaged about Julian day 81 (22 March) at Bande-Amir NP and Julian day 65 (6 March) for Ajar PWR, but varied by about one month depending on the year.

Soil information is limited to general or regional descriptions, with the area dominated by Lithic Cryoborolls with inclusions of Cryorthents and Cryaquolls.i The soils have formed mostly under a semidesert environment with cold winters with some areas of wetlands associated with subirrigated conditions. Most soils are gray to grayish-brown soils (sierozems or aridisols) derived from calcareous rocks with some areas of brown steppe soils and are relatively shallow with little B horizon development and no organic layer.

\footnotetext{
i" http://jasper.brc.tamus.edu/afghanistan/default.aspx. Accessed 9 August
} 2010. 


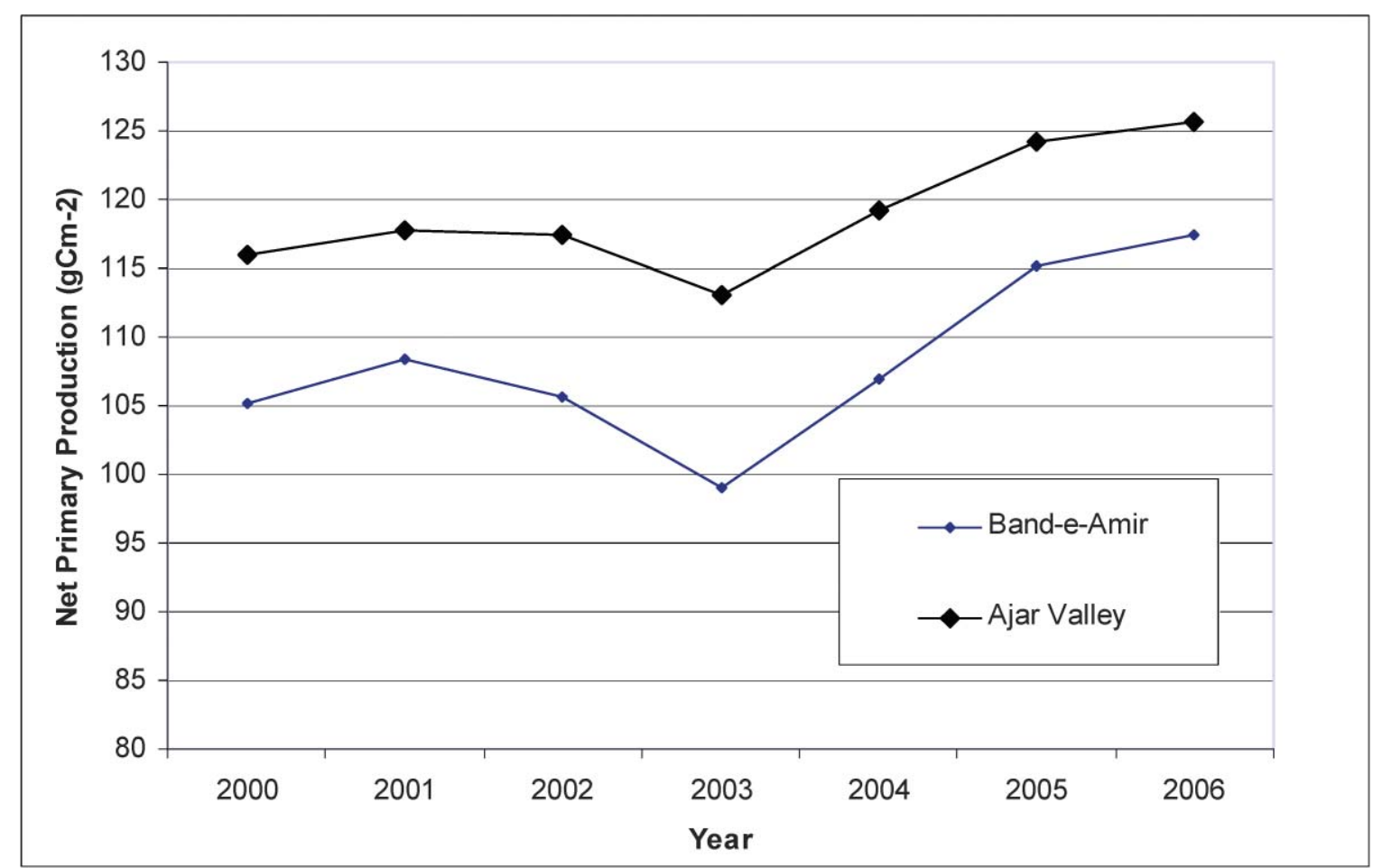

Figure 5. Annual net primary production $\left(\mathrm{g} \mathrm{C} / \mathrm{m}^{2}\right)$ for Band-e-Amir NP and Ajar PWR derived from subsetting global data. ${ }^{11}$ Data set available at: ftp://ftp.ntsg.umt.edu/pub/MODIS/Mirror/MOD17A3.305/Improved_MOD17A3_C5.1_GEOTIFF_1km; accessed 22 December 2009.

An interesting aspect of the highly calcareous nature of the soils is associated with the formation of the lake dams (see Fig. 2). These dams are made up of the mineral travertine that is formed when gaseous carbon dioxide from calciumrich spring water is driven out, causing the dissolved calcite to precipitate out, forming mineral deposits. Over time these mineral deposits build on a submerged surface of dead and living vegetation, forming a terrace or dam over time.

\section{Rangeland Types}

Following a review of the literature and a rapid rangeland reconnaissance we separated the rangelands into six broad types: 1) an Artemisia-Acantholimon steppe, 2) a semidesert shrub, 3) a juniper steppe, 4) a canyon-bottom complex, 5) a riparian shrub, and 6) a wetland and sedge meadow. Each type includes several plant communities, but only a few of the more common community types are described. The descriptions are broad but provide the reader with a general overview of the rangelands, its uses, and its values. Further research is needed to classify potential vegetation types and to provide information on how these communities respond to livestock grazing and other human impacts.

\section{Artemisia-Acantholimon Steppe}

The largest rangeland type in the Ajar PWR and Band-eAmir NP is the Artemisia-Acantholimon steppe. The term steppe is used in a very broad sense to include sparse to relatively dense cover of low shrubs. It has been hypothesized that much of the Artemisia steppe of the central highlands is not the natural vegetation, but was originally a grass steppe converted to an Artemisia steppe with centuries of heavy grazing. ${ }^{6,10,13}$ Certainly, increased grazing pressure has reduced grass cover and increased unpalatable species; however, we suggest that an Artemisia steppe, much like that seen in the western United States, is a natural vegetation type of the area. Similarly, on some of the more productive sites, vegetation dominated by grasses with few shrubs is likely a natural condition. The Artemisia-Acantholimon steppe is potentially quite productive, supplying an important grazing resource for livestock and wild species. In Ajar PWR, Allocasuarina lebmanniana and Ephedra spp. were used by ibex in this type. ${ }^{7}$ Shrubs, including cushion shrubs, are important to local people as their main fuel source. The more productive sites of this rangeland type in Bande-Amir have often been plowed, which has led to significant degradation and reduction of livestock forage and wildlife habitat.

We divided the Artemisia-Acantholimon steppe into two community types: 1) an Artemisia steppe where potential grass cover was greater than 35\% canopy cover and cushion shrubs infrequent; and 2) a Acantholimon-Astragalus cushion shrub community where Artemisia was infrequent, cushion shrubs common, mainly Acantholimon species (Plumbaginaceae), and natural grass canopy cover was hypothesized at less than $35 \%$. Other community types certainly exist associated with different grazing pressures and site characteristics, but these two community types were common. The Artemisia shrubs are generally about $0.5 \mathrm{~m}$ or 


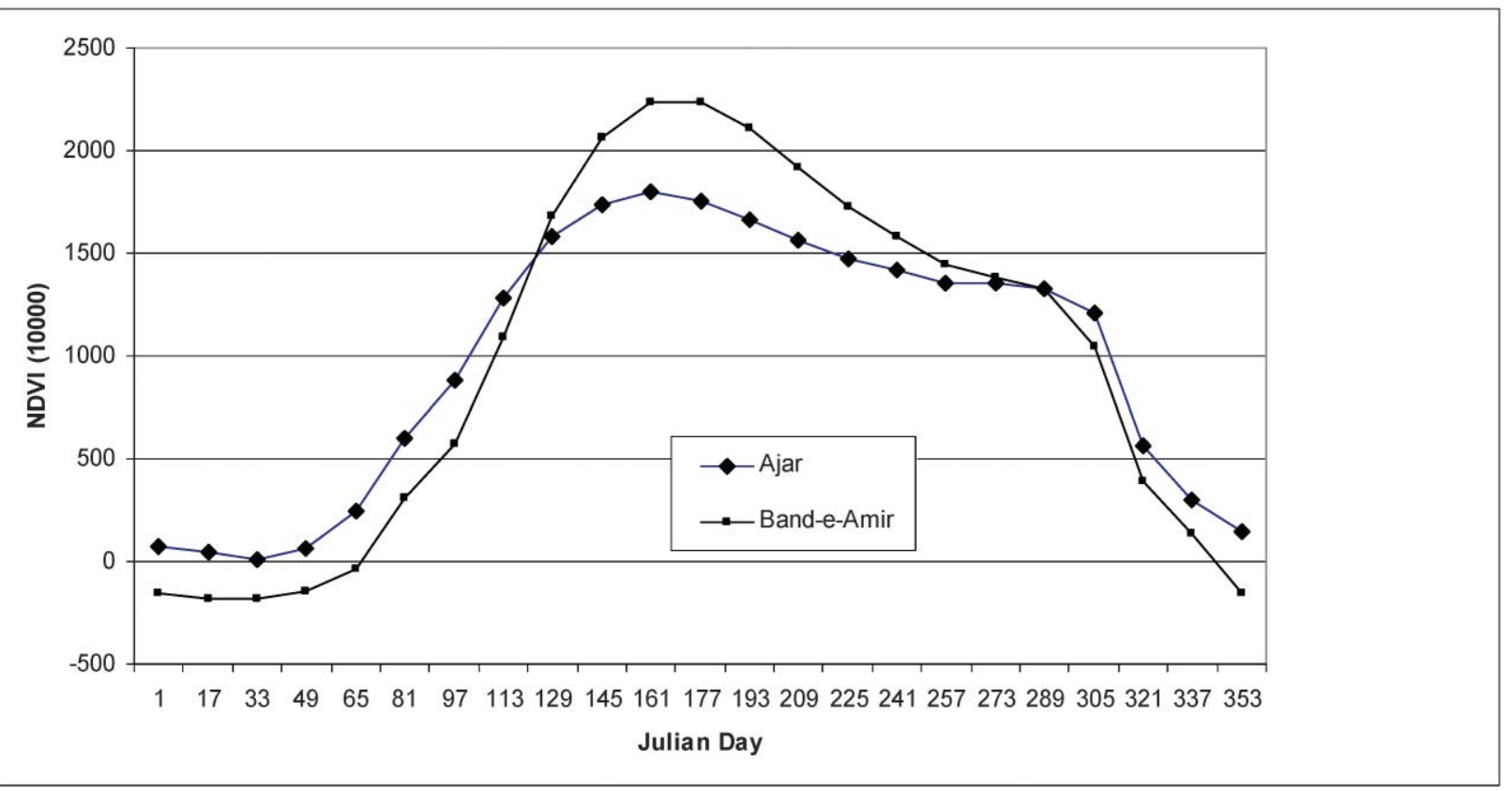

Figure 6. Mean normalized difference vegetation index $(N D V I \times 10,000)$ for Ajar provisional wildlife refuge and Band-e-Amir National Park for the years 2000-2004 and 2008-2009. NDVI is from MODIS composites (MOD1301) vegetation indices (cloud screened) at 250-m resolution; available at: https:///pdaac.usgs.gov/Ipdaac/get_data/data_pool. Accessed 23 February 2010.

less in height, and the cushion shrubs can vary in size from a small plant to one of $1 \mathrm{~m}$ in diameter depending on species and age. The most common Artemisia shrub is A. lehmanniana, a shrub generally $30-50 \mathrm{~cm}$ in height found mostly between elevations of 2,800 $\mathrm{m}$ to $3,200 \mathrm{~m}$. Grasses found in both community types were sheep fescue (Festuca ovina), needle grasses (Stipa szowitsiana and Stipa trichoides), wildryes (Elymus spp.), Russian wildrye (Psathyrostachys juncea), and bluegrasses (Poa spp.). Annual grasses such as downy brome (Bromus tectorum) and medusahead rye (Taeniatherum caput-medusae) were present but not common. Common half-shrubs and forbs included Artemisia dracunculus and other Artemisia spp., several mints in the genera Nepeta, Salvia, Scutellaria, and Hymenocrater, several spiny Cousinia spp., Russian knapweed (Acroptilon repens), as well as geophytes such as wild tulips and Eremus spp., a very attractive lily-like forb. Astragalus species are also common, and some are shrub-like (such as Astragalus cuneifolius).

The Artemisia steppe community type can produce significant forage. On three sites in Ajar PWR where livestock grazing was somewhat limited by topographic barriers (some grazing did occur), grass production was estimated at $800 \mathrm{~kg} / \mathrm{ha}$, and mean canopy cover of grasses, Artemisia shrubs, and cushion shrubs (predominately Acantholimon spp.) were $52 \%, 9 \%$, and $2 \%$, respectively. Grass canopy cover on similar sites with no barrier to livestock grazing had perennial grass cover varying from $1 \%$ to $20 \%$. The Artemisia steppe community type often intergrades to a semidesert shrub rangeland type at lower elevations and on warm, dry aspects and the Acantholimon-Astragalus community type at higher elevations.
The Acantholimon-Astragalus community type was generally found at higher elevations and could be classified as a subalpine cushion shrub community. However, frequently this community type was intermixed with the Artemisia steppe. The forage production in this community type was lower than in the Artemisia steppe community type, but the cushion shrubs are important as a source of fuel for local peoples. Six Acantholimon species are found in Bande-Amir. ${ }^{6}$ Other genera found in this community that were cushion shrubs included Onobyrychis, Astragalus, and Acanthophyllum. A similar community type was designated as an Acantholimon steppe where Acantholimon was the dominant plant type. ${ }^{7}$ We did not measure sites where Acantholimon was the dominant cover, but this may be associated with heavy selection of this genus by locals for fuel. We hypothesize that the growth rates of these cushion shrubs are quite slow. Because of recent heavy shrub harvests, Acantholimon cover has likely been significantly reduced on most sites.

\section{Semidesert Shrub}

A semidesert shrub rangeland type is found at lower elevations $(1,925 \mathrm{~m}$ to $2,800 \mathrm{~m})$ and on dryer aspects (Fig. 7). Intermingled with this type are relatively large barren areas with little vegetation. Several semidesert shrub types were identified. Taller shrubs such as Zygophyllum atriplicoides and Haloxylon griffithi dominated the most common type. The H. griffithi was often found in depressions with greater salinity. All of these semidesert shrub types have low herb cover and productivity (with the shrubs widely). On sites dominated by $Z$. atriplicoides and $H$. griffithi, shrub height 


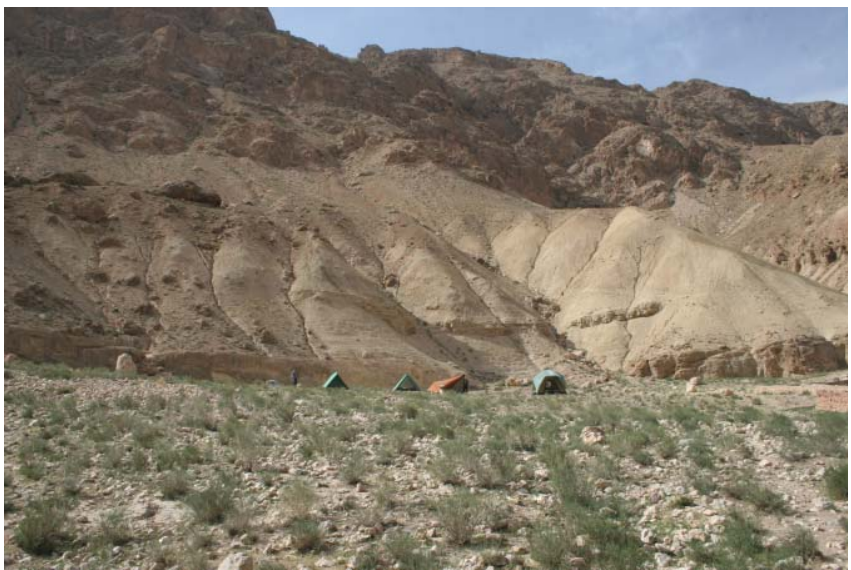

Figure 7. Photo of semidesert shrub dominated by Zygophyllum atriplicoides and Haloxylon griffithi community with one of our camps in the background in Ajar Provisional Wildlife Refuge.

approached $1 \mathrm{~m}$. These sites were classified as Zygophyllum steppe, ${ }^{7}$ but perennial grass cover averaged less than $1 \%$ during our sampling, making the term "steppe" seem inappropriate. This type is common in Ajar PWR but is uncommon in Band-e-Amir NP, where it is found mostly widely scattered on dry slopes. An Ephedra semidesert shrub community type occurred on rocky sites. This community type was generally found as small inclusions within the above mentioned semidesert shrub types. As the semidesert shrub types become cooler and wetter (east and north slopes), Artemisia lebmanniana, Acantholimon spp., needlegrasses, ricegrass (Oryzopsis spp.), and Eremurus kaufmannii increase with the dominant semidesert shrubs. Salsola species and large Apiaceae species as well as Cousinia and grasses may be locally abundant.

The Zygophyllum steppe was considered one of the poorest range types in Ajar PWR ${ }^{7}$ but supplies an important winter grazing resource, and the shrubs are used for fuel. The long grazing history could be the main factor in low perennial grass cover, but without enclosures it is difficult to hypothesize about the length of time for perennial grass cover to significantly increase. In enclosures within Zygophyllum and Artemisia semideserts in the Touran Biosphere Reserve in northeastern Iran, grass composition increased after only 18 months of protection from grazing. ${ }^{14}$ As such, one could speculate that even on these dryer semidesert shrub types grass productivity would increase with reduced grazing pressure.

\section{Juniper Steppe}

Scattered widely through Ajar PWR is juniper steppe with widely spaced Juniperus excelsea. The juniper has growth forms varying from spreading low shrubs to moderately tall shrubs to large trees. This type was described as remnant woodland decimated through overexploitation. ${ }^{7}$ Other herb and shrub species are similar to the Artemisia-Acantholimon steppe described above. This type is important for aesthetic values and wildlife habitat, but in general supplies relatively

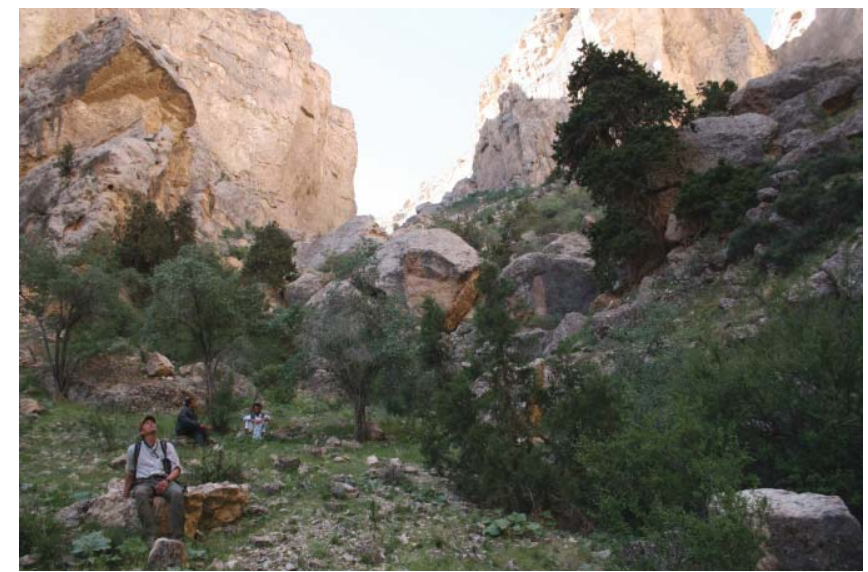

Figure 8. Canyon bottom remnant woodland with large Juniper exce/sea in Ajar provisional wildlife reserve.

low to moderate forage for livestock. Juniper was not observed in Band-e-Amir NP, and it is unknown if this type once occurred in Band-e-Amir NP but was eliminated by human use. Juniper in Ajar PWR was mostly found growing on rock cliffs, canyon bottoms, or other areas with some protection from woodcutting. Juniper shrubs often had significant damage associated with cutting of stems for fuel. There is a restriction on cutting live juniper that is enforced sporadically by police, and as removal of dead juniper is allowed, people kill juniper by burning or girdling plants. We observed many donkey loads of juniper being transported to nearby villages, and there is little doubt that juniper will be eliminated from the area without agreements to protect areas where juniper occurs.

\section{Canyon-Bottom Complex}

The canyon bottoms often form a unique environment where many different plant communities exist. As such, this type is a mixture of many communities with species from mesic woodlands to semidesert and is grouped here based on location within canyons (Fig. 8). Ajar PWR, with numerous canyons and highly dissected drainages, has many more of these canyon-bottom communities than Band-e-Amir NP. These canyon bottom communities vary according to specific factors: 1) water availability and time of season (some water is available much later because of melting snow), 2) soils (landslides and erosional deposition result in young soils), and 3) human use (in some canyons the bottoms are major trailing routes, and excessive shrub use and heavy grazing have greatly impacted vegetation). In many of the broad canyon bottoms a salt shrub type is found where Zygophyllum atriplicoides and Haloxylon griffithii dominate and herb cover was almost nonexistent. These sites appeared to have high levels of salts associated with deposition processes where fine soils and salts are deposited in the canyon bottoms. In some very narrow canyon bottoms and steep side drainages, livestock grazing and human impacts have been minimal. In these areas we often found 
a woodland community with Juniper excelsea, Cotoneaster spp., Berberis integerrima, and a rich herb cover. These sites have value for their aesthetics, wildlife value, and likely as "nurseries" for seeds of many species that are overused outside these semiprotected environments.

\section{Riparian Shrublands}

Numerous shrub-dominated community types are found along streams. These communities are some of the most productive communities, but also the most limited associated with crop agriculture, intensive livestock grazing, and other human uses. The most productive is a Salix shrub type that is dominated by Salix species, but other shrubs may form a significant amount of the overstory. In Ajar PWR the riparian willow community is associated with the Ajar River. In Band-e-Amir NP this community was found along several streams. The most common Salix species are Salix pycnostacya and Salix schugnanica. A poplar (Populus afghanica) is also found along some streams. This poplar and the Salix excelsea are planted along irrigation ditches and some streams for use as timber in homes. Other riparian shrub communities were associated with dominance of Myricaria germanica (tamarix family) or caragana (Caragana aurantiaca). Other common shrubs are silverberry (Eleagnus angustifolia), roses (Rosa spp.), sea buckthorn (Hippophae rhamnoides), and hawthorn (Crataegus turkestanica). Sedges (Carex spp.) and rushes (Juncus spp.) form the dominant cover, but often these communities are quite diverse with numerous herbs. Species found in this habitat and the United States include Kentucky bluegrass, red fescue, bent grasses (Agrostis spp.), quackgrass, reedgrasses (Calamagrostis spp.), bluegrasses, alkali grass (Puccinellia spp.), foxtails (Aloepecurus spp.), common reed (Phragmites australis), Mentha spp. or mints, red clover (Trifolium repens), plantain (Plantago lanceolatea), dandelions (Taraxacum spp.), buttercups (Ranunculus spp.), geraniums (Geranium spp.), Iris spp., Gentiana spp., wild carrot (Daucus carota), and others.

The riparian shrub communities provide cover and food for wildlife and livestock. Salix is used for making baskets, and wood is used for fuel and other domestic purposes. In the Ajar area this type, and surrounding rangeland types, were used by a herd of Bactrian deer introduced in 1955. This herd apparently flourished when the Ajar area was protected from hunting; however, following the loss of protection, all of the Bactrian deer were apparently killed, probably before 1990 .

\section{Wetlands and Sedge Meadows}

Wetland and sedge meadows are two types grouped here as both are generally dominated by sedges (Carex spp.) and occur in subirrigated conditions. Although small in area these types are very productive and important as a grazing resource. The wet meadows are often adjacent to or intermingled with riparian shrub communities with many of the same species. The difference between wet meadows

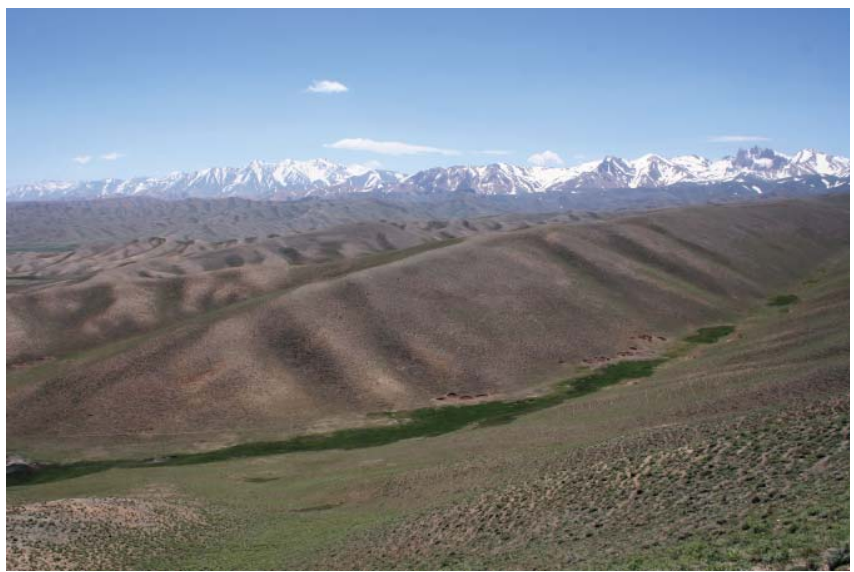

Figure 9. A sedge meadow (green area) dominated by Carex stenophylla and surrounded by predominately Artemisia-Acanotholimon steppe, Band-e-Amir National Park.

and riparian shrub communities is that the wet meadow is generally wet throughout the growing season, often with "boggy" conditions and few shrubs. Many wet meadows have a relatively large cover of a beautiful reddish purple orchid (Dactylorbiza umbrosa). The wet meadows are dominated by sedges (Carex spp.), spikerush (Eleocharis palustris), bull rushes (Scirpus spp.), other rushes (Juncus spp.), and numerous other herbs similar to the riparian shrub type. One poisonous plant common to this type is arrowgrass (Triglochin spp.). A marsh or shoreline vegetation type also occurs in a few areas along lake or pond shores where shallow-water and fine sediments form marsh vegetation dominated by tall reeds. Marshes are important habitat for nesting birds and cover for wild species, and the local people use the reeds for winter livestock fodder and for roofing material. Major species include common reed, bull rush, and cattails (Typha beome).

A Carex stenophylla-dominated sedge meadow often occurs in depressions where snow has accumulated or at the base of valleys where there is a greater amount of available water, creating temporary subirrigated conditions (Fig. 9). Bulbous bluegrass (Poa bulbosa), buttercups, Inula rhizocephala, and Lagotis spp. are common species, with plant cover varying between $25 \%$ and $100 \%$ cover. Ibex prefer these areas during the spring, and these areas are also preferred by livestock. ${ }^{7}$ These sedge meadows are often found within the Artemisia-Acantholimon steppe where sheep fescue is used by ibex and livestock. Carex stenophlla was considered to be tolerant to heavy grazing, ${ }^{7}$ but there is little doubt this type is being significantly impacted by heavy livestock grazing.

\section{Resource Issues and Concerns}

We determined rangeland issues and concerns by reviewing literature, conducting informal interviews with local people and government officials, and using our rapid rangeland reconnaissance. Three issues most often identified were overgrazing, unsustainable harvest of shrubs, and plowing of 


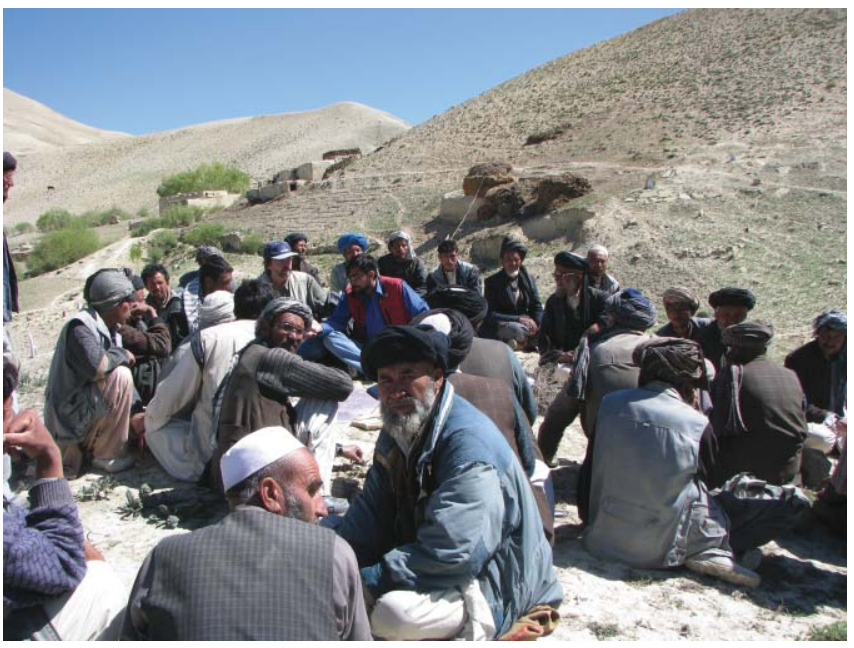

Figure 10. Participatory rural appraisal with villagers to discuss concerns and possible solutions related to over-harvest of shrubs. Note large stacks of shrubs in the background and overgrazed Artemisia steppe.

marginal lands. Loss of wildlife is a critical issue that we did not explore in detail, but it is an obvious issue, especially in Ajar PWR. In Ajar PWR, hunting of ibex has decimated the population, probably now numbering fewer than 100 compared to several thousand in the 1970s.

\section{Unsustainable Shrub Use}

Shrubs are used for cooking and, along with manure, for heating by all households. There is strong agreement that lack of fuel is a critical problem. As such, we initiated a modified participatory rural appraisal (PRA) in five randomly chosen Band-e-Amir villages to examine shrub use (Fig. 10). The most important shrubs were generally the same species in the five villages surveyed. Villagers separated the different Acantholimon spp. based on their importance as fuel or animal feed or both. It was learned that red ghuzbai (probably Acantholimon auganum) was used as both fuel and animal feed, whereas the other two Acantholimon species (probably Acantholimon poliochlorum and Acantholimon erinaceum) were considered only fuel. The woody Astragalus cuneifolius, a species similar in appearance to tree cholla cactus (Cylindropuntia imbricata), was predominately mentioned as fuel and not as feed. This tall woody shrub may also be important as a nitrogen fixer and no doubt is important in providing cover to wild species. A plant the villagers called kbirpak (an unknown Cousinia) was listed in three of the five PRAs as an important fuel and feed plant. This forb has a woody base that is used as fuel, and the top portion was saved as feed for animals in the winter. PRA participants often mentioned forage value of the Artemisia and of surkhpaicha (Polygonum podlechii) but stressed that these were collected only as a fuel source and not as stored feed for animals.

All interviews substantiated that shrub availability had dramatically decreased in recent times. It was difficult to get the groups to suggest the level of change, but some indicated as much as an $80 \%$ decrease in the last five years, a level that seems too high. Others stated that the problem was that they now had to travel two to three times farther to collect shrubs. At one village PRA we were told that 30 years ago adequate large shrubs were easy to collect near the village area, but now they had to travel $7 \mathrm{~km}$ to find shrubs of adequate size. In all but one village the main reason given for the decrease in shrubs was associated with overharvesting by "outsiders." These outside collectors were generally from villages outside of Band-e-Amir NP or from Bamyan town (the capital of Bamyan Province). The PRA participants stated that outside collectors often used trucks and collected all the shrubs, leaving little to repopulate the site. In one village the PRA participants stated that shrubs were declining mostly because of the drying climate, with outside collectors a second but smaller factor. When asked what could be done about the outside collectors, the villagers said they needed to be able to control their areas and had petitioned local government to support their need to restrict use. However, in all cases these villagers stated that the provincial government had done nothing to help their village restrict outside use of their village lands.

Because it was stressed that the decrease in shrubs was greatest in the last five years, we were curious if "outsiders" collecting shrubs were not a problem in the past. Indeed, many of the villagers stated that during mujahedeen times (late 1970s until 2001) trucks would come, and they were forced to cut shrubs and load the trucks. Some also stated that mujahedeen would come at other times and just take shrubs that were stored for household use. In one instance Pashtun were identified as the group coming from outside to gather shrubs. We asked if these were kuchi (nomads) and were told no. These villagers then stated that the kuchi did not overuse shrubs or collect shrubs outside their areas, implying again that the problems regarding overuse of shrubs was not by traditional users of these rangelands. We found it surprising that no group interviewed suggested that other local people (people from adjacent villages) were considered a problem in the reduction of shrubs in their village area. This suggests that either this practice was not done or an accepted norm. In one village an individual did state that one reason for the decline of shrubs was associated with increased dryland cultivation. This individual was quickly scolded by other villagers, as there is no doubt that villagers are concerned about land use restrictions, especially regarding dryland cultivation. We never asked specifically if dryland farming was decreasing shrubs because we did not want to suggest why shrubs were decreasing. However, there is no doubt that dryland farming has significantly decreased shrubs and decreased the productivity of grazing areas.

In four of the villages, PRA participants stated that the greatest use of shrubs is in winter. During this period they used four donkey loads each week (a donkey load was estimated as about $70 \mathrm{~kg}$ by locals). In one village participants stated that greatest use was in spring and summer 


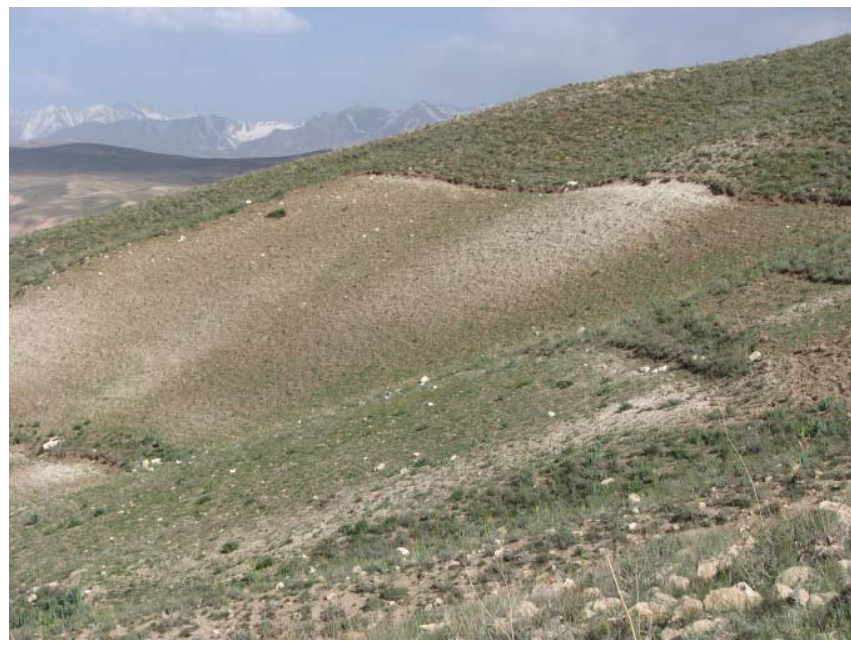

Figure 11. Photo of cultivated area ( $/ a / m i)$ on a steep slope within a productive area of Artemisia steppe, Band-e-Amir National Park.

because more fuel was needed to boil milk. In interviews with shrub collectors, we were told that a family uses about $7,000-8,000 \mathrm{~kg}$ of shrubs per year. When considering the areas where there are no shrubs (cultivated areas, water, roads, and wetlands) and harvest of shrubs by outsiders the amount of shrub use in Band-e-Amir averages well over $100 \mathrm{~kg} /$ year. There is little doubt that the level of shrub removal is not sustainable and needs to be addressed by park officials.

\section{Plowing of Rangelands}

Dryland farming, called lalmi, is a historic use in Band-eAmir NP. Today the government turns a blind eye to the practice because food security for local people is such a critical issue. The main crop is wheat that is planted in April or May and harvested in August. The wheat is mostly used to produce a flatbread or nan, a staple for Afghans. The bread is baked in a tandoor, a cylindrical oven made of clay, and heated with shrubs collected from the rangelands. The bread is stuck to the wall of the heated oven and then cooked. This traditional cooking practice is where most of the shrubs are used.

Information is lacking on the economics of lalmi at Band-e-Amir NP. There is no doubt that because of the scarcity of grain, people continue to expand the practice to more marginal lands. Some areas of lalmi are on slopes of $20 \%$ or more with evident soil loss (Fig. 11). In some years, especially on marginal sites, the grain harvested is minimal. In one interview we were told that the straw from some fields is more valuable than the grain with the straw used as animal feed and in construction material to make adobe. A common practice is to rest the land after one crop, with one villager stating that each area received six years rest following planting. Others stated that the rest period may range from three to seven years, and it was not evident how rest periods were determined. During the rest period there is no attempt to plant a cover crop or to protect the site from wind or water erosion using conservation tillage practices. These areas produce almost no forage for livestock. Apparently for most sites the area is abandoned after only a few plantings as grain yield decreases. From our interviews it seems that about $25 \%$ of the area previously dryland farmed is now used. Again, this would seem to suggest that the amount of cultivated area would increase as the food needs of the growing human population increase.

Almost all plowing is with a wooden plow pulled by an ox. This practice limits annual area plowed and how deeply the land is tilled. In Band-e-Amir NP, a tractor has recently been used to plow some areas. This practice has been prohibited by the local park management committee, although it is unknown if the prohibition can be upheld. As stated previously, the economics of dryland farming needs study and logically if the practice is unsustainable restoration of rangelands should be implemented. There is no doubt that the plowing has significantly reduced shrub and grass production and decreased soil carbon, fertility, and wildlife habitat over rather large areas in Band-e-Amir NP. The loss of carbon sequestration, grazing values, shrubs, as well as aesthetic values and biodiversity aspects all point to a strong need to understand the costs and benefits of the lalmi. We hypothesize that succession would take 30 years to reestablish a shrub steppe, based on succession on abandoned sites. Using conservation tillage practices, some of the area could be farmed in a more sustainable manner. However, it is obvious that the steeper hillsides should not be plowed. Therefore, there is an immediate need to provide a land capability classification for placing or delineating sites into areas with low, moderate, high, and severe potential for soil erosion and crop failure based on site characteristics such as soils, soil depths, and slope.

\section{Livestock Grazing and Rangeland Health}

Concern regarding overgrazing was evident in literature regarding Band-e-Amir $\mathrm{NP}^{15}$ but was not considered an issue by local villagers interviewed. As stated previously, Ajar PWR was only lightly grazed by domestic livestock from about 1950 to the mid-1980s and as such was not an issue in any previous reports. Nomadic herders grazed animals on the border of Ajar Valley and sometimes within the reserve, but the extent of this was considered to be minimal. ${ }^{8}$ Livestock numbers are unknown for Ajar PWR as local users are wary of providing information to outsiders. Estimated livestock numbers for Band-e-Amir NP were 7,000 sheep and goats, 1,360 cattle, and 1,540 horses and donkeys, ${ }^{16}$ but local people provided much higher estimates in 2008. ${ }^{9}$ Little information is available on historic numbers of livestock, but in the mid-1970s it was reported that local households grazed 10,000 sheep and goats, 1,500 cattle, 300 oxen, and 200 horses yearlong, and about 260 nomadic families grazed 15,000 to 30,000 livestock during the summer in Band-e-Amir. ${ }^{15}$ As such, past livestock numbers were greater than present estimates. The kuchi families that grazed Band-e-Amir NP in the past have been mostly 
excluded from the area for at least 15 years as a result of confrontations with the local Hazara population.

Rangeland health was estimated on 30 upland range sites (no lalmi areas were selected) using indicators of rangeland health. We had no information on ecological sites or reference conditions, so our procedure provides only a rough estimate of soil and site stability, hydrologic function, and biotic integrity. In the Ajar PWR, 20\% of the sites were rated as having ecological processes functioning within a normal range of variation; however, three out of four of these sites were in areas where livestock grazing was partially restricted by topographical features. Eleven sites (55\%) had evidence reflecting a moderate to extreme departure in soil and site stability, hydrologic function, or biotic integrity. The remaining sites $(25 \%)$ were less clear in their trends, and these sites were categorized as stable to slightly "unhealthy." At Band-e-Amir, we estimated that $90 \%$ of the sites had clear evidence reflecting a moderate to extreme departure in soil and site stability, hydrologic function, or biotic integrity. The remaining $10 \%$ were less clear in their trends and these sites were categorized as stable to slightly "unhealthy."

Of the categories used to indicate changes in ecological function, bare ground, plant composition and distribution relative to infiltration, plant functional and structural groups, and annual production were most often considered having the greatest departure from perceived natural ecological function. Livestock grazing has reduced grass cover and altered plant composition and plant functional groups, especially by reducing perennial grasses, and in annual production as a decline in grass productivity. Grasses are mostly found beneath shrubs or protected by rocks. Very little litter is present on most sites except occasionally around shrubs. Obviously, in the dryer low-elevation sites low soil organic matter and low amounts of litter are natural, but we believe grazing has exacerbated the situation by removing almost all grasses on some sites. Harvesting of shrubs and other plants (e.g., Ferula asafoetida) creates site degradation by decreasing vegetation cover and disturbing soil surface conditions. We watched as locals removed shrubs by "grubbing" the plants out, often digging up perennial grasses at the base of the shrubs. These shrubs also modify soil conditions by holding litter and organic matter at the shrub base, reducing flow of wind and water across the site, and holding snow. The moderate to extreme level of departure of ecological function in Band-e-Amir NP is thus considered a result of long-term grazing pressure and shrub harvest. As stated previously lalmi areas were not included in this analysis, but obviously these areas show the most dramatic departure in ecological function. We suggest that even though rangeland health is compromised, there is a strong potential for improvement because "remnant" forage plants are present. The continued overgrazing and overharvesting of shrubs threaten this potential for recovery. The shrubs provide important protection to perennial grasses and other forage species. Over time the overharvesting of shrubs will lead to significant loss of "remnant" forage plants.
As local people do not consider overgrazing a problem, it will be difficult to convince herders that new grazing management is needed. Also, to develop any grazing management program that may reduce livestock numbers is a formidable task as livestock production is significant to the livelihoods of local people, and there are few to no opportunities to grow supplemental feeds or to open new grazing areas. These factors all point to a strong need for developing other livelihood options for villagers.

\section{Summary and Management Recommendations}

Band-e-Amir NP and Ajar PWR are important for their unique habitats and religious and cultural values. These areas are dominated by rangelands varying from wetlands to semidesert shrublands, which are grazed by sheep, goats, donkeys, horses, cattle, and in the past by numerous wild ungulates. The rangelands also supply local people with their fuel (shrubs), herbs, and medicinal plants. Unsustainable harvest of shrubs is the most critical issue in Band-e-Amir NP and Ajar PWR. Plowing of rangelands is a critical problem in Band-e-Amir NP but is restricted to only a few areas in Ajar PWR. Overgrazing is a concern in some areas, especially near villages, and the increased degradation caused by overharvesting of shrubs and increased dryland cultivation degrades grazing land productivity and exacerbates livestock grazing problems. Wild ungulates and large predators are now mostly absent in these areas. In Ajar PWR some ibex remain, estimated at fewer than 100 compared to several thousand in the $1970 \mathrm{~s},{ }^{8}$ and urial are seen occasionally in both Band-e-Amir and Ajar PWR areas. The loss of wildlife is associated with poaching and loss of habitat. Larsson $^{7}$ stated, "compared to the adjacent, over-exploited rangelands, the Ajar Wildlife Reserve shows throughout its history of protection signs of general range improvement that are considered unique for the central Afghanistan highland." It is extremely unfortunate that this protection was so completely lost by the 1980s, and there is little doubt that current human uses are continuing to degrade these rangelands. However, we believe that some rangeland areas of Ajar PWR are still some of the least degraded rangelands we have seen in Afghanistan. To ensure that these areas are not lost to overuse, and that wildlife populations can survive, conservation planning needs to begin as soon as possible. Designation of the Ajar PWR as a "protected area or conservation area" will provide the legal basis for management and protection measures necessary to conserve wildlife populations, scenic values, and the natural environment. Conserving these values and designation of the area as a protected area would also ensure that benefits accrue to local people in an organized and effective manner.

Band-e-Amir National Park is well known for its clear, blue lakes and surrounding scenic landscapes, but these are threatened by unsustainable rangeland uses. The designation of Band-e-Amir as Afghanistan's first national park in 2009 provides for renewed tourism and conservation interests, but 
the area is under constant threat associated with its growing population and poor resource management. The plowing of rangelands, overharvesting of shrubs, and overgrazing need immediate attention or livelihoods of local peoples will continue to deteriorate. There is an immediate need to determine if there are culturally acceptable fuel-efficient stoves available that could reduce fuel use. In Band-e-Amir NP it is recommended that a rangeland program be initiated that includes four major projects: 1) development of community shrub collection areas to protect these areas from outside collectors and to provide incentives for local villages to initiate methods of proper shrub use to initiate shrubland recovery; 2) land classification of dryland farming areas and agreement on which areas (slopes and soils) could be plowed in the future (included would be a study examining costs and benefits of dryland farming); 3) installation of reference ecological sites (exclosures) in some shrub areas and in some abandoned cultivated areas for determining length of time for vegetation recovery; and 4) establishment of grazing management plans for villages (including agreedon exclusive community grazing areas to provide incentives for better grazing management). As such, the proposed rangeland program could be used to develop a model (with modifications learned) for rangeland improvement in similar areas in Afghanistan. Improved rangeland management in Afghanistan is critical for improving environmental conditions and livelihoods in Afghanistan.

\section{Acknowledgments}

We thank the Wildlife Conservation Society, New York, and the United States Agency for International Development (USAID) for support of this work. Also, we would like to thank Mr Sayed Humayoon, MoA, for his assistance, and the assistance of numerous rangers in Band-e-Amir National Park and local guides in the proposed Ajar Valley Wildlife Reserve.

\section{References}

1. Ewans, M. 2002. Afghanistan: a short history of its people and politics. New York, NY, USA: Harper Collins Publishers. $338 \mathrm{p}$.

2. Mousavi, S. A. 1997. The Hazaras of Afghanistan: an historical, cultural, economic, and political study. New York, NY, USA: Palgrave Macmillan. 265 p.

3. Wiley, L. A. 2009. Suggested strategy for conflict resolution of competing high pasture claims of settled and nomadic communities in Afghanistan. Kabul, Afghanistan: United Nations Development Programme. 134 p.

4. Zabriskie, P. February 2008. Hazaras: Afghanistan's outsiders. Available at: http://ngm.nationalgeographic.com/2008/ 02/afghanistan-hazara/phil-zabriskie-text. Accessed 3 January 2010.

5. Wiley, L. A. 2004. Looking for peace on the pastures: rural land relations in Afghanistan. Kabul, Afghanistan: Afghanistan Research and Evaluation Unit. 111 p.

6. Dieterle, A. 1973. Vegatations kundliche Untersuchungen im Gebiet von Band-i-Amir (Zentral Afghanistan) [dissertation]. Munich, Germany: University of Munich. 83 p. [In German.]
7. Larsson, J. Y. 1978. Status of alpine rangelands in central Afghanistan with special reference to the Ajar Valley Wildlife Reserve. FO: DP/AFG/74/016. Kabul, Afghanistan: United Nations Development Program, Food and Agricultural Organization. 48 p.

8. Shank, C. C., R. G. Petocz, and K. Habibi. 1977. A preliminary management plan for the Ajar Valley Wildlife Reserve. FO: DP/AFG/78/007. Kabul, Afghanistan: United Nations Development Program, Food and Agricultural Organization. $50 \mathrm{p}$.

9. Ministry of Agriculture, Irrigation and Livestock. 2008. Band-i-Amir Provisional National Park: a preliminary management plan 2008-2011. Kabul, Afghanistan: Ministry of Agriculture, Irrigation and Livestock. 54 p.

10. Freitag, H. 1971. Studies in the natural vegetation of Afghanistan. In: P. H. Davis. [ED.]. Plant life of Southwest Asia. Edinburgh, Scotland: Royal Botanic Garden. p. 89-106.

11. Zhao, M., F.A. Heinsch, R. R. Nemani, and S. W. Running. 2005. Improvements of the MODIS terrestrial gross and net primary production global date set. Remote Sensing of Environment 95:164-176.

12. Laurenroth, W. K. 1979. Grassland primary production: North American grasslands in perspective. In: N. French [ED.]. Ecological studies 32: perspectives in grassland ecology. New York, NY, USA: Springer. p. 3-24.

13. Sayer, J. A., And A. P. M. van der Zon. 1981. Afghanistan: national parks and wildlife management: a contribution to a conservation strategy. FO: DP/AFG/78/007. Technical Report, vol. I. Rome, Italy: United Nations Development Programme and Food and Agriculture Organization. 107 p.

14. Breckle, S. W. 1983. Temperate deserts and semi-deserts of Afghanistan and Iran. In: N. E. West [ED.]. Temperate deserts and semi-deserts. 5th series. Ecosystems of the world. New York, NY, USA: Elsevier Scientific Publishing. p. 271-319.

15. Shank, C. C., And Larsson, J. Y. 1977. A strategy for the establishment and development of Bande Amir National Park. FO:DP/AFG/AFG/74/016, field document no. 8, December. Kabul, Afghanistan: United Nations Development Programme and Food and Agriculture Organization. 37 p.

16. Asian Development Bank. 2006. Land use plan for proposed Band-e-Amir NP National Park. TA-451 AFG: natural resources management and poverty reduction. Draft document, August. Kabul, Afghanistan: Asian Development Bank. 25 p.

\section{Additional Reading}

Barfield, T. J. 1981. The central Asian Arabs of Afghanistan: pastoral nomadism in transition. Austin, TX, USA: University of Texas Press. $182 \mathrm{p}$.

Michener, J. 1973. Caravans: a novel of Afghanistan. New York, NY, USA: Fawcett Crest.

Robinett, D., D. Miller, and D. Bedunah. 2008. Central Afghanistan rangelands: a history of tribal rule, grazing, war and rebuilding. Rangelands 30:2-12.

Authors are Professor, Department of Forest Management, University of Montana, Missoula, MT 59812, USA, don. bedunah@cfc.umt.edu (Bedunah); and Consultant (Shank) and Hazarajat Conservation Specialist (Alavi), Wildlife Conservation Society, Kabul, Afghanistan. 